\title{
Application of Multispectral Images to Monitor the Productive Cycle of Vines Fortified with Zinc ${ }^{\dagger}$
}

\author{
Diana Daccak 1,2**D, Cláudia Campos Pessoa ${ }^{1,2} \mathbb{D}$, Ana Rita F. Coelho ${ }^{1,2} \mathbb{D}$, Ana Coelho Marques ${ }^{1,2} \mathbb{D}$, \\ Inês Carmo Luís ${ }^{1,2} \mathbb{D}$, João Caleiro ${ }^{1,2}$, Maria Manuela Silva ${ }^{2,3} \mathbb{D}$, Manuela Simões ${ }^{1,2} \mathbb{D}$, \\ Fernando H. Reboredo 1,2 $\mathbb{D}$, Maria Fernanda Pessoa 1,2 $\mathbb{D}$, Paulo Legoinha 1,2 $\mathbb{D}$, Maria Graça Brito ${ }^{1,2} \mathbb{D}^{\mathbb{D}}$, \\ José Carlos Kullberg ${ }^{1,2}{ }^{\mathbb{D}}$, José António Almeida ${ }^{1,2} \mathbb{D}$, Paula Scotti Campos ${ }^{2,4}$ (D) José C. Ramalho ${ }^{2,3}$ \\ and Fernando C. Lidon ${ }^{1,2}$
}

check for updates

Citation: Daccak, D.; Pessoa, C.C.; Coelho, A.R.F.; Marques, A.C.; Luís, I.C.; Caleiro, J.; Silva, M.M.; Simões, M.; Reboredo, F.H.; Pessoa, M.F.; et al. Application of Multispectral Images to Monitor the Productive Cycle of Vines Fortified with Zinc. Biol. Life Sci. Forum 2021, 3, 4. https://doi.org/ 10.3390/IECAG2021-09665

Academic Editor: Youssef Rouphael

Published: 30 April 2021

Publisher's Note: MDPI stays neutral with regard to jurisdictional claims in published maps and institutional affiliations.

Copyright: (c) 2021 by the authors. Licensee MDPI, Basel, Switzerland. This article is an open access article distributed under the terms and conditions of the Creative Commons Attribution (CC BY) license (https:// creativecommons.org/licenses/by/ $4.0 /)$.
1 Earth Sciences Department, Faculdade de Ciências e Tecnologia, Universidade Nova de Lisboa, 2829-516 Caparica, Portugal; c.pessoa@campus.fct.unl.pt (C.C.P.); arf.coelho@campus.fct.unl.pt (A.R.F.C.); amc.marques@campus.fct.unl.pt (A.C.M.); idc.rodrigues@campus.fct.unl.pt (I.C.L.); jc.caleiro@campus.fct.unl.pt (J.C.); mmsr@fct.unl.pt (M.S.); fhr@fct.unl.pt (F.H.R.); mfgp@fct.unl.pt (M.F.P.); pal@fct.unl.pt (P.L.); mgb@fct.unl.pt (M.G.B.); jck@fct.unl.pt (J.C.K.); ja@fct.unl.pt (J.A.A.); fjl@fct.unl.pt (F.C.L.)

2 GeoBioTec Research Center, Faculdade de Ciências e Tecnologia, Universidade Nova de Lisboa, 2829-516 Caparica, Portugal; abreusilva.manuela@gmail.com (M.M.S.); paula.scotti@iniav.pt (P.S.C.); cochichor@mail.telepac.pt (J.C.R.)

3 PlantStress \& Biodiversity Lab, Centro de Estudos Florestais, Instituto Superior Agronomia, Universidade de Lisboa, 2784-505 Oeiras, Portugal

4 INIAV, Instituto Nacional de Investigação Agrária e Veterinária, 2780-157 Oeiras, Portugal

* Correspondence: d.daccak@campus.fct.unl.pt

$+\quad$ Presented at the 1st International Electronic Conference on Agronomy, 3-17 May 2021; Available online: https://sciforum.net/conference/IECAG2021.

Abstract: In the context of an exponentially growing population and resource limitations, precision agriculture techniques can improve efficiency in the agricultural sector. This can be achieved by monitorization and quick detection of changes in crops, resulting in smart resource use, waste reduction and maximization of production. In a field located in Palmela (Portugal), three foliar sprays of $\mathrm{ZnO}$ and $\mathrm{ZnSO}_{4}$ were performed in Vitis vinifera variety Fernão Pires, for production of biofortified single-vine wine. Field characterization was performed with soil sampling and UAVs (with altimetric measurement sensors), synchronized by GPS. Vegetations indexes and characterization of drainage capacity and slopes were then interpolated with mineral content, monitored with X-ray Fluorescence analysis. Morphologically, the experimental parcel had a slight slope (maximum of $1.10 \mathrm{~m}$ ) with irrigation and nutrient availability in soil requiring special attention (i.e., just one-third of the parcel had higher capacity to water drainage). NDVI values reflected better physiological values in the $\mathrm{N}-\mathrm{NE}$ region. Zinc increases in leaves were directly proportional with the applied concentrations in vines sprayed with $\mathrm{ZnSO}_{4}$ and $\mathrm{ZnO}$; the concentration of $60 \%\left(900 \mathrm{~g} \mathrm{ha}^{-1}\right)$ revealed a greater vigor. In conclusion, the use of smart farm techniques and their crossing with analytical procedures allows the characterization and monitoring of vines, and a higher potential for optimization of wine production.

Keywords: biofortification; grapes; NDVI; precision agriculture; remote sensing; Vitis vinifera; zinc

\section{Introduction}

At a nutritional level, Zn deficits represent a serious health problem, affecting onethird of the world's population [1,2]. This micronutrient is one of the most abundant trace elements of the human organism, with average values of about 1.5-2.5 g in adults [2]. Additionally, it has important physiological functions in the immune system, sensory capacity, neurobehavioral development, reproductive health, growth and physical development [3]. 
To prevent nutritional deficiencies alternatives have emerged, namely agronomic biofortification, to increase mineral density at responsive growth stages of crop plants, through soil and/or foliar applications [4,5]. Moreover, foliar spraying seems to be more efficient in the capture and allocation of nutrients than soil application [5].

Countries that have a Mediterranean climate are prone to $\mathrm{Zn}$ deficiency in crops [6]. In plants, Zn performs important roles linked to plant development, reproduction and signaling, due to its structural, catalytic and activating functions, and also as a cofactor for some enzymes [7]. Besides, its deficiency is the most common cause of yield reductions in numerous crops [8].

For a sustainable agriculture, it is necessary to resort to new technologies to monitor activities related to control and decision-making, namely through images obtained with cameras coupled to Unmanned Aerial Vehicle (UAVs), which allow us to acquire information about crop water stress, the photochemical reflectance index, and the vegetation indices [9]. Through normalized difference vegetation index (NDVI), it is further possible to obtain information about crops productivity, because it measures photosynthetic activity, correlating positively with chlorophyll content and, therefore, with nitrogen levels in plants [10].

The wine industry contributes to Portugal's agricultural sector, and in 2018, over 176,800 ha were destined for wine production [11]. According to [12], Portugal holds the 11th position in the world rank of wine producers, with a production of $6.1 \mathrm{mhl}$.

In this study, UAVs were used for characterization of a vineyard where a Zn workflow was being carried out, namely morphologic parameters such as slopes and related aptitude for surface water drainage. Furthermore, the assessment of the physiologic response of vineyards after spraying with $\mathrm{ZnSO}_{4}$ and $\mathrm{ZnO}$ was performed to monitor the impact of the workflow on plants, which was then correlated with Zn concentration in leaves.

\section{Materials and Methods}

\subsection{Experimental Field}

The experimental field is located in the region of Palmela, Portugal, with the coordinates $\mathrm{N} 38^{\circ} 35^{\prime} 41.467^{\prime \prime} \mathrm{O} 8^{\circ} 50^{\prime} 44.535^{\prime \prime} \mathrm{W}$ and corresponds to a vineyard with Fernão Pires variety. A $\mathrm{Zn}$ biofortification workflow was performed with two types of treatments: $\mathrm{ZnSO}_{4}$ and $\mathrm{ZnO}$ with concentrations of $0,10,30$ and $60 \%$ (corresponding to 0, 150, 450 and $900 \mathrm{~g} \mathrm{ha}^{-1}$ ). Foliar spraying was performed with three applications along the reproductive cycle, between 16 of June and 6 of August. Harvest was carried out at 17 September.

\subsection{Fiel Morphology and NDVI}

Acquisition of multispectral and altimetry images was performed through an Unmanned Aerial Vehicle (UAV), equipped with an RGB camera attached (to obtain the orthophotomap and altimetry model), and a multispectral camera (Parrot Sequoia), to attain images corresponding to the near infrared (NIR) region and the Red-Edge of the electromagnetic spectrum [13]. The design of maps was elaborated through the Agisoft Photoscan and ArcMap (Agisoft, 2018; ESRI, 2019), namely: orthomosaic, models elevation systems, slope maps and vegetation indexes.

\subsection{Quantification of $\mathrm{Zn}$ in Grape Leaf's}

Accumulation of $\mathrm{Zn}$ in randomized grape leaves was analyzed after three foliar sprays, using a XRF analyzer (model XL3t 950 He GOLDD+), under He atmosphere [14]. The grape leaves were cut, dried (at $60^{\circ} \mathrm{C}$, until constant weight), ground and processed into pellets.

\section{Results}

Morphologically, the terrain where the workflow took place is almost flat (Figure 1a), presenting a maximum variation of $1.10 \mathrm{~m}$ in the area of sprayed vineyard, implying a soft inclination. Regarding surface drainage conditions (Figure 1b), only one-third of the total 
land area reflected aptitude for infiltration of surface waters. Furthermore, NDVI index values indicated a better physiological response in the N-NE zone (Figure 1c).
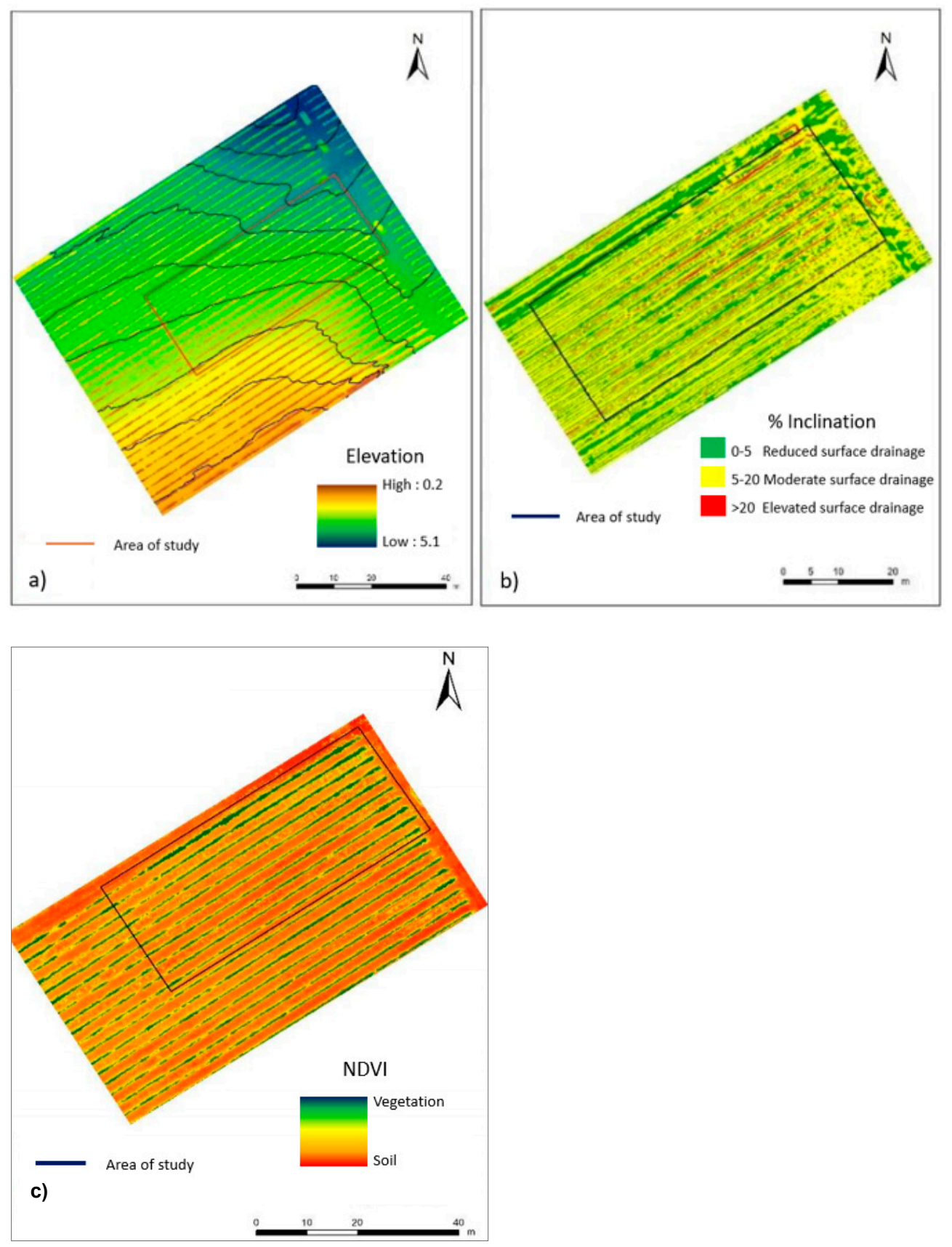

Figure 1. Digital elevation model (a), digital map of slopes (b), and NDVI model (c), from the experimental field acquired on 27 June 2018 (after three foliar sprays).

Zinc's mineral content in leaves after three foliar applications with $\mathrm{ZnSO}_{4}$ and $\mathrm{ZnO}$, were directly proportional with the applied concentrations (Figure 2). Rows sprayed with higher concentrations of $\mathrm{Zn}$ for each treatment (OZn60 and SZn60) presented higher mineral content, and all sprayed rows showed higher concentration of $\mathrm{Zn}$ in leaves in comparison to the control. Additionally, rows sprayed with $\mathrm{ZnO}$ presented greater vigor in comparison to rows sprayed with $\mathrm{ZnSO}_{4}$. Less vigor was observed for rows $\mathrm{SZn} 30$ and SZn10, where values were inferior to the control. 


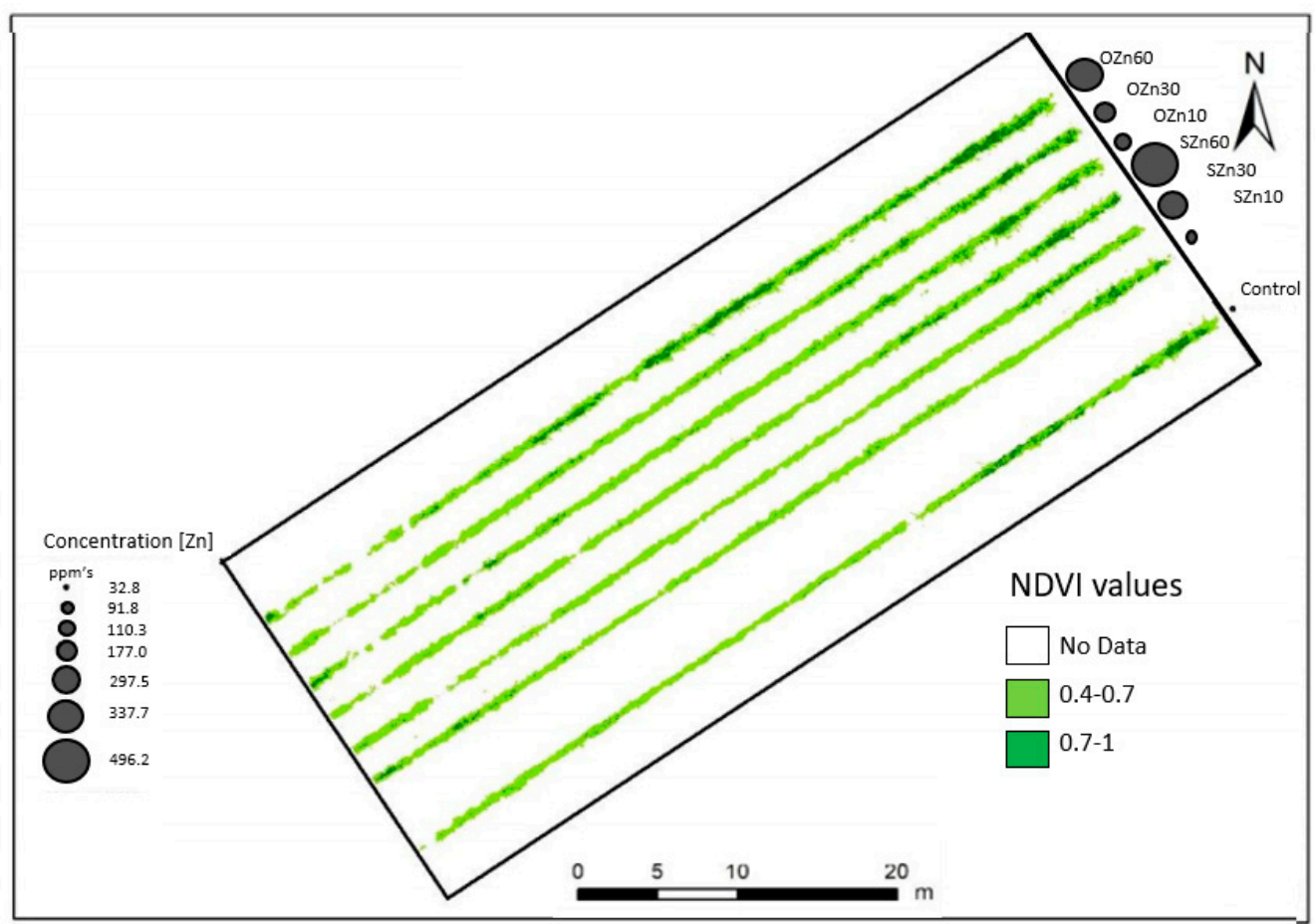

Figure 2. Representation of zinc concentration in leaves from Vitis vinifera, Fernão Pires variety, and the respective vigor of plants using the NDVI vegetation index, acquired at 27th June 2018 (after three foliar sprays). Scales of [0.4-0.7] and [0.7-1.0] were used. OZn10, OZn30 and OZn60 correspond to pulverization of zinc oxide in concentrations 150, 450 and $900 \mathrm{~g} \mathrm{ha}^{-1}$, respectively. SZn10, SZn30 and SZn60 correspond to pulverization of zinc sulfate in concentrations 150, 450 and $900 \mathrm{~g} \mathrm{ha}^{-1}$, respectively. No foliar sprays were applied on control.

\section{Discussion}

Vineyards' development, and ultimately fruit growth, depend on edaphoclimatic conditions and viticulture practices [15]. Accordingly, surface water drainage can be influenced by terrain morphology, namely since planar zones tend to accumulate this water and thus promoting its infiltration on soil [16]. The information attained from UAVs, specifically regarding drainage, suggests that attention must be given to water availability for this terrain, in order to assure the necessary uptake of nutrients from soils, since poorly drained or with high salt content soils, affects grape crop's capacity to thrive under such soil conditions [17]. However, the development of a deep root system helps grape crops to adjust to limited water supply and large productions can still be attained under rainfed conditions, but soils with high water capacity are recommended if summer rain does not occur [17]. For this terrain, irrigation throughout fruit development is no longer performed since a deep root system has been developed as this crop is composed of older vines.

On the other hand, the slight inclination of the terrain can be connected to a better physiologic response on the N-NE zone, which presents a lower elevation in comparison to the S-SW zone. Since water tends to accumulate in this zone, the predisposition to deficits in mechanisms of nutrient absorption from soil and movement of photosynthesis products to other tissues is minimized [18]. This can be linked to a prominence of higher NDVI values in the $\mathrm{N}-\mathrm{NE}$ zone, implying that the applied Zn workflow did not have a negative impact on vineyards. Since NDVI values vary between -1 and 1 , with values closer to 1 indicating healthy vegetation $[19,20]$, this vineyard in general does not present values related to stressed vegetation.

The most common source used as $\mathrm{Zn}$ fertilizer is $\mathrm{ZnSO}_{4}$, due to its high solubility and low cost [21], yet it was observed in sunflower plants that $\mathrm{ZnO}$ was also effective, enhancing the amount of $\mathrm{Zn}$ in all plants [22]. According to [23,24], fertilization with sources of $\mathrm{Zn}$, lead to an increase in this mineral's concentration in leaves of Pistachio trees, 
in sweet orange and Feutrell's early mandarin plants. Furthermore, in a study with a grape variety, 'Shine Muscat', this increase was observed after Zn fertilization through foliar and soil application [25]. Data of Zn content in leaves obtained in this study are in agreement with the other works previously mentioned, revealing an increase in $\mathrm{Zn}$ content in leaves after three foliar applications with both treatments $\left(\mathrm{ZnSO}_{4}\right.$ or $\left.\mathrm{ZnO}\right)$, prevailing a higher rise with treatment $\mathrm{ZnSO}_{4}$ (Figure 2). These increases provide better chances for $\mathrm{Zn}$ content in fruits to rise by translocation mechanisms. Supplementary Materials.

\section{Conclusions}

The use of precision agriculture techniques, namely images processed from cameras coupled to UAVs, in the vineyard submitted to the reported workflow for Zn enrichment allowed terrain characterization in terms of slopes and water drainage, to identify possible conditionings to the increase in Zn in fruits. Furthermore, NDVI enabled the assessment to different physiological responses in different zones of the vineyard, which can be related to the characteristics of the field.

The applied workflow using foliar application of $\mathrm{Zn}$ did not present negative influences in the vineyard, and increases in $\mathrm{Zn}$ in leaves from Fernão Pires variety occurred with $\mathrm{ZnO}$ and $\mathrm{ZnSO}_{4}$. In both cases, $\mathrm{Zn}$ content rose with the increase in concentration, which became relevant, as assimilation of $\mathrm{Zn}$ by leaves through foliar sprays is crucial for this mineral's increase in fruits by translocation mechanisms, and thus needed to attain fruits with added value.

Supplementary Materials: The following are available online at https:/ / www.mdpi.com/article/10 .3390/IECAG2021-09665/s1.

Author Contributions: Conceptualization, P.S.C., J.C.R. and F.C.L.; methodology, M.G.B., J.C.K. and F.C.L.; software, M.G.B.; formal analysis, D.D., C.C.P., A.R.F.C., A.C.M., I.C.L., J.C. and J.C.K.; resources, M.M.S., M.S., F.H.R., M.F.P., P.L., M.G.B., J.C.K., J.A.A. and F.C.L.; writing-original draft preparation, D.D. and C.C.P.; writing-review and editing, D.D., C.C.P. and F.C.L.; supervision, F.C.L.; project administration, F.C.L.; funding acquisition, F.C.L. All authors have read and agreed to the published version of the manuscript.

Funding: This research was funded by PDR2020, grant number 101-030727.

Acknowledgments: The authors thanks to Adega Cooperativa de Palmela and Casa Agrícola Nunes Oliveira da Silva Lda. for technical assistance. We also give thanks to the Research centers (GeoBioTec) UIDB/04035/2020 and (CEF) UIDB/00239/2020 for support facilities.

Conflicts of Interest: The authors declare no conflict of interest. The founding sponsors had no role in the design of the study; in the collection, analyses or interpretation of data; in the writing of the manuscript or in the decision to publish the results.

\section{References}

1. Mangueze, A.V.J.; Pessoa, M.F.G.; Silva, M.J.; Ndayiragije, A.; Magaia, H.E.; Cossa, V.S.I.; Reboredo, F.H.; Carvalho, M.L.; Santos, J.P.; Guerra, M.; et al. Simultaneous zinc and selenium biofortification in rice. Accumulation, localization and implications on the overall mineral content of the flour. J. Cereal Sci. 2018, 82, 34-41. [CrossRef]

2. Rugeles-Reyes, S.M.; Cecílio Filho, A.B.; López Aguilar, M.A.; Silva, P.H.S. Foliar application of zinc in the agronomic biofortification of arugula. Food Sci. Technol. 2019, 39, 1011-1017. [CrossRef]

3. Liu, D.; Liu, Y.; Zhang, W.; Chen, X.; Zou, C. Agronomic approach of zinc biofortification can Increase zinc bioavailability in wheat flour and thereby reduce zinc deficiency in humans. Nutrients 2017, 9, 465. [CrossRef]

4. Bhatt, R.; Hossain, A.; Sharma, P. Zinc biofortification as an innovative technology to alleviate the zinc deficiency in human health: A review. Open Agric. 2020, 5, 176-187. [CrossRef]

5. Valença, A.W.; Bake, A.; Brouwer, I.D.; Giller, K.E. Agronomic biofortification of crops to fight hidden hunger in sub-Saharan Africa. Glob. Food Sec. 2017, 12, 8-14. [CrossRef]

6. Noulas, C.; Tziouvalekas, M.; Karyotis, T. Zinc in soils, water and food crops. J. Trace Elem. Med. Biol. 2018, 49, 252-260. [CrossRef]

7. Balafrej, H.; Bogusz, D.; Triqui, Z.A.; Guedira, A.; Bendaou, N.; Smouni, A.; Fahr, M. Zinc hyperaccumulation in plants: A Review. Plants 2020, 9, 562. [CrossRef] [PubMed]

8. Ullah, A.; Farooq, M.; Rehman, A.; Hussain, M.; Siddique, K.H.M. Zinc nutrition in chickpea (Cicer arietinum): A review. Crop Pasture Sci. 2020, 71, 199-218. [CrossRef] 
9. Popescu, D.; Stoican, F.; Stamatescu, G.; Ichim, L.; Dragana, C. Advanced UAV-WSN System for Intelligent Monitoring in Precision Agriculture. Sensors 2020, 20, 817. [CrossRef] [PubMed]

10. Hogrefe, K.R.; Patil, V.P.; Ruthrauff, D.R.; Meixell, B.W.; Budde, M.E.; Hupp, J.W.; Ward, D.H. Normalized difference vegetation index as an estimator for abundance and quality of avian herbivore forage in arctic Alaska. Remote Sens. 2017, 9, 1234. [CrossRef]

11. I.P. Instituto Nacional de Estatística. Estatísticas Agrícolas: 2018; INE: Lisbon, Portugal, 2019; pp. $13-32$.

12. International Organisation of Vine; Wine I.O. 2019 Statistical Report on World Vitiviniculture; OIV: Paris, France, $2019 ;$ p. 14.

13. Coelho, A.R.F.; Lidon, F.C.; Pessoa, C.C.; Marques, A.C.; Luís, I.C.; Caleiro, J.C.; Simões, M.; Kullberg, J.; Legoinha, P.; Brito, G.; et al. Can Foliar pulverization with $\mathrm{CaCl}_{2}$ and $\mathrm{Ca}\left(\mathrm{NO}_{3}\right)_{2}$ trigger Ca enrichment in Solanum Tuberosum L. tubers? Plants 2021, 10, 245. [CrossRef] [PubMed]

14. Luís, I.C.; Lidon, F.C.; Pessoa, C.C.; Marques, A.C.; Coelho, A.R.F.; Simões, M.; Patanita, M.; Dôres, J.; Ramalho, J.C.; Silva, M.M.; et al. Zinc Enrichment in two contrasting genotypes of Triticum aestivum L grains: Interactions between edaphic conditions and foliar fertilizers. Plants 2021, 10, 204. [CrossRef] [PubMed]

15. FAO. Agribusiness handbook- Grapes Wine; FAO: Rome, Italy, 2009; pp. 7-12.

16. Pessoa, C.C.; Lidon, C.F.; Coelho, A.R.F.; Caleiro, J.C.; Marques, A.C.; Luís, I.C.; Kullberg, J.C.; Legoinha, P.; Brito, M.G.; Ramalho, J.C.; et al. Calcium biofortification of Rocha pears, tissues accumulation and physicochemical implications in fresh and heat-treated fruits. Sci. Hortic. Amster. 2021, 277, 109834. [CrossRef]

17. FAO-Land and Water. Available online: http://www.fao.org/land-water/databases-and-software/crop-information/grape/ en/ (accessed on 8 March 2021).

18. Taiz, L.; Zeiger, E. Plant Physiology, 3rd ed.; Sinauer Associates: Sunderland, UK, 2002.

19. Shafi, U.; Mumtaz, R.; García-Nieto, J.; Hassan, S.A.; Zaidi, S.A.; Iqbal, N. Precision agriculture techniques and practices: From considerations to applications. Sensors 2019, 19, 3796. [CrossRef]

20. Loures, L.; Chamizo, A.; Ferreira, P.; Loures, A.; Castanho, R.; Panagopoulos, T. Assessing the effectiveness of precision agriculture management systems in mediterranean small farms. Sustainability 2020, 12, 3765. [CrossRef]

21. Cakmak, I. Enrichment of cereal grains with zinc: Agronomic or genetic biofortification? Plant Soil 2008, 302, 1-17. [CrossRef]

22. Torabian, S.; Zahedi, M.; Khoshgoftar, A.H. Effects of foliar spray of two kinds of zinc oxide on the growth and ion concentration of sunflower cultivars under salt stress. J. Plant Nutr. 2016, 39, 172-180. [CrossRef]

23. Ibrahim, Z.R. Effect of Spraying Zinc, Copper and iron on leaf nutrient, fruit set and some fruit quality of pistachio trees (Pistacia vera L.) cv. Halebi. J. Univ. Duhok 2020, 23, 218-227. [CrossRef]

24. Ahmad, I.; Bibi, F.; Ullah, H.; Munir, T.M. Mango fruit yield and critical quality parameters respond to foliar and soil applications of zinc and boron. Plants 2018, 7, 97. [CrossRef]

25. Yao, L.; Zhu, J.; Li, Z.; Wang, Y.; Zhou, X.; Wang, J. Effects of zinc fertilizer on photosynthetic characteristics of 'Shine Muscat' grape. E3S Web Conf. 2019, 136, 07017. [CrossRef] 